\title{
IgA antibody response during acquired and congenital toxoplasmosis
}

\author{
MH Bessières, C Roques, A Berrebi, V Barre, M Cazaux, JP Séguéla
}

\begin{abstract}
Toxoplasma gondii specific IgA and IgM antibodies were quantitated by an antibody capture agglutination assay in 260 patients with acquired toxoplasmosis and from 94 fetuses suspected of congenital toxoplasmosis and 30 infected children. In acquired toxoplasmosis, IgA antibodies to $T$ gondii were found in $95 \%$ of the cases. In congenital toxoplasmosis IgA antibodies were more frequently detected $(75 \%)$ in cord blood than IgM antibodies (61\%). They persisted after birth, in some cases for up to 24 months. IgA antibodies were also detected in fetuses whose mothers had toxoplasmosis during their pregnancy. In infected fetuses IgM and IgA antibodies were detected in fetal blood as early as week 24 of pregnancy.

Detection of IgA $T$ gondii antibodies may be useful for the diagnosis of some recently acquired infection and for the diagnosis and follow up of the infection in the fetus and neonate.
\end{abstract}

Tomoplasmosis is usually a benign infection in immunocompetent subjects, but it can be serious in congenitally infected patients and in the immunocompromised (those with AIDS and bone marrow or heart transplant recipients). The diagnosis of toxoplasmosis is most often based on serological tests which detect IgG and IgM antibodies. Difficulties persist in diagnosing this infection because specific IgM antibodies may be detected by immunocapture assays long after the initial infection. Moreover, in these tests naturally occurring antibodies to Toxoplasma gondii lead to false positive results. ${ }^{1}$ However, IgM antibodies are not evident in all cases of congenitally acquired toxoplasmosis.

Laboratoire de
Parasitologie
Mycologie, CHU
Rangueil, 31054
Toulouse Cedex,
France
MH Bessières
C Roques
V Barre
M Cazaux
JP Séguéla
Services de
Gynécologie
Obstétrique A-B-C,
Hôpital La Grave,
Toulouse Cedex,
France
A Berrebi
Correspondence to:
MH Bessières
Accepted for publication
28 November 1991

\section{Methods}

Serum samples were obtained from three groups. Group I comprised 260 serum samples collected from adults with acquired toxoplasmosis and characterised by the presence of specific IgG and IgM antibodies. One hundred and forty eight sera were obtained from 46 pregnant women who seroconverted during pregnancy, collected one to eight months after seroconversion. These patients were seronegative at the onset of pregnancy and were followed up monthly using serology during the course of pregnancy. They were treated with spiramycin as soon as toxoplasmosis was diag- nosed, and the treatment was continued throughout the pregnancy. One hundred and twelve sera were collected before or after pregnancy and divided into two groups: 64 "acute" sera obtained during the first six months after seroconversion; and 48 "chronic" sera collected more than six months to two years after the onset of infection. Group II consisted of 385 sera and formed a control group: 193 sera were obtained from patients with an immunity which had been acquired more than two years earlier (the presence of IgG antibodies detected by immunofluorescence but IgM negative was used as a control) and 192 come from uninfected patients negative for IgG and IgM antibodies. Eighteen sera with naturally occurring IgM antibodies $(n=13)$ or rheumatoid factor $(n=5)$ were also included in this group. Group III included infants with congenital toxoplasmosis: 318 sera were collected at birth (cord blood) and in the following months 120 sera were obtained from 30 infants with congenital toxoplasmosis and 198 from 54 uninfected infants born from mothers who seroconverted during pregnancy. Congenital infection or absence of infection was established by serological study.

An increase in IgG antibody titres was observed during the first year in congenital toxoplasmosis. However, IgG antibodies decreased and disappeared in uninfected infants. Two hundred and twenty four sera consisted of fetal blood sampled between 20 and 32 weeks of gestation by direct needle puncture under ultrasound guidance. ${ }^{2}$ In each case pure fetal blood $(2-4 \mathrm{ml})$ was obtained. Fetal blood was analysed to determine whether maternal contamination had occurred, as described previously. ${ }^{2}$ Amniotic fluid and maternal serum were also sampled. Ninety four fetal blood samples were collected for a prenatal diagnosis of toxoplasmosis. Pregnant women sampled for a diagnosis other than toxoplasmosis made up a control group; 130 fetal blood samples were obtained for a prenatal diagnosis of chromosomic disorders.
SEROLOGICAL TESTS

Each patient's serum was tested using each serological test. Immunofluorescence for detection of IgG antibodies, IgM enzyme linked immunosorbent assay and IgM immunosorbent assay (IgM ISAGA) were performed as described previously. ${ }^{3-5}$ Total IgG, IgM, and IgA immunoglobulins were measured in cord blood by laser immunonephelometry. ${ }^{6}$ The IgA immunocapture assay (IgAIC) was performed as described by Le 


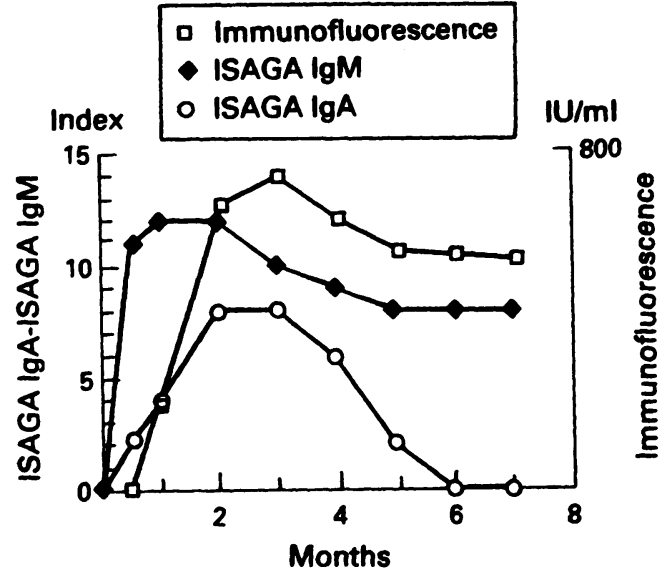

Figure Kinetics of $\operatorname{Ig} A, \operatorname{IgG}$, and IgM antibodies in acquired toxoplasmosis (mean value obtained from 46 pregnant women who seroconverted during pregnancy).

Fichoux ${ }^{7}$ and Pinon et al, ${ }^{8}$ with some modifications. Plate coating was on wells of microtitration plates (Microwell NUNC 964, Polylabo France) sensitised with an antihuman IgA monoclonal antibody diluted to $2 \mu \mathrm{g} / \mathrm{ml}$ (Biosoft, France). Serum samples were diluted at 1 in 50 and fetal blood at 1 in 20 . Diluted serum $(100 \mu \mathrm{l})$ was placed in each well. After two hours of incubation at $37^{\circ} \mathrm{C}$ in a moist chamber and three washings in PBS (pH 7.2) a fixed concentration of killed tachyzoites $(100 \mu \mathrm{l})$ were added to each well $\left(10^{7} \mathrm{~T}\right.$ gondiil $\mathrm{ml})$. The plates were then incubated overnight at $37^{\circ} \mathrm{C}$ in a moist chamber. Each test included a negative control (value 0), a positive control, and an antigen control. Sera were positive when agglutination was observed in the well. An index of 4 was noted when a toxoplasma agglutination was observed in a mat covering the base of the well. Intermediate indexes were noted 1 to 3 , as in the IgM ISAGA. When the test had an index of 2 or more, sera were again tested with three concentrations of antigens: 100,150 , and $200 \mu \mathrm{l}$ of the antigenic suspen-

Table 1 Results of detection of IgG, IgA and IgM anti-T gondii antibodies in 28 samples of cord blood from congenitally infected children

\begin{tabular}{lcccc}
\hline & & \multicolumn{3}{c}{ Trimester of maternal infection } \\
\cline { 3 - 5 } $\begin{array}{l}\text { Detection of antibodies } \\
\text { in cord blood }\end{array}$ & Case numbers & 1st & 2nd & 3rd \\
\hline IgG + IgA + IgM+ & 14 & 0 & 4 & 10 \\
IgG + IgA + IgM- & 7 & 1 & 6 & 0 \\
IgG + IgA - IgM + & 3 & 0 & 2 & 1 \\
IgG + IgA - IgM - & 4 & 2 & 2 & 0 \\
& 28 & 3 & 14 & 11 \\
\hline
\end{tabular}

Table 2 Results obtained from sera collected at birth (cord blood) and during the first six months (one $\rightarrow$ six months) in children with congenital toxoplasmosis

\begin{tabular}{|c|c|c|c|c|c|c|c|}
\hline & \multirow[b]{2}{*}{ Cord blood at birth } & \multicolumn{6}{|c|}{ Months } \\
\hline & & 1 & 2 & 3 & 4 & 5 & 6 \\
\hline $\begin{array}{l}\text { Positive IgA antibodies } \\
\text { Positive IgM antibodies }\end{array}$ & $\begin{array}{l}21 \\
17\end{array}$ & $\begin{array}{l}5 \\
6\end{array}$ & $\begin{array}{l}3 \\
4\end{array}$ & $\begin{array}{l}2 \\
2\end{array}$ & $\begin{array}{l}1 \\
1\end{array}$ & 1 & $\begin{array}{l}1 \\
0\end{array}$ \\
\hline $\begin{array}{l}\text { Number of congenital } \\
\text { toxoplasmosis serum }\end{array}$ & 28 & 16 & 16 & 12 & 7 & 15 & 11 \\
\hline
\end{tabular}

sion $\left(10^{7} T\right.$ gondii $\left./ \mathrm{ml}\right)$ were dispensed with the same procedure as in the confirmatory test in IgM ISAGA. ${ }^{5}$ An index of 0 to 2 indicated a negative reaction, 3 to 5 a borderline reaction, and 6 to 12 a positive reaction. In congenital toxoplasmosis an index of 3 or more was regarded as positive.

\section{Results}

IGA AND IGM ANTIBODY RESPONSE IN ACQUIRED TOXOPLASMOSIS

IgA and IgM antibodies were not detected in 385 sera of the control group, including 192 uninfected patients and 193 subjects with acquired immunity. In the group with acute toxoplasmosis the presence of IgA antibodies was studied at different stages of acute infection (less than six months). IgA antibodies were detected at the end of the first month of infection. The maximum rate of positive cases was observed during the second and third months. IgA antibodies followed the same course as IgM antibodies. IgM antibodies were the first to be produced between days 7 and 15; IgA antibodies were produced at the end of the first month. IgM and IgA antibodies increased in parallel. The maximum concentration of specific IgM was reached two months after the contamination and that of IgA between two and three months. IgA antibodies disappeared before IgM antibodies between months 4 and 7. IgG antibodies detected by immunofluorescence followed the same course as IgA antibodies in the first months of acquired toxoplasmosis. They increased during the two months following the infection (figure). During the chronic phase of infection, which lasted more than six months, 48 sera with positive IgM antibodies tests showed only specific IgA antibodies in two cases. In chronic infection IgA antibodies were almost never detected. The samples with naturally occurring IgM antibodies or rheumatoid factors did not have IgA antibodies. The presence of IgA antibodies associated with IgM antibodies is an index of an acute infection. Simultaneous detection of IgA, IgM, and IgG antibodies facilitates the acurate timing of onset of infection, but IgA antibodies were not detected in all cases of recent toxoplasmosis. In $5 \%$ of such cases specific IgA could not be shown.

IGA AND IGM ANTIBODY RESPONSE IN

CONGENITAL TOXOPLASMOSIS

The detection of IgA and IgM antibodies was performed in 28 samples of cord blood from congenitally infected children. IgA antibodies were detected in 21 out of $28(75 \%)$ cases and IgM antibodies in 17 out of $20(61 \%)$ cases (table 1). IgA antibodies were not always associated with IgM antibodies. The serological profile of newborns was a function of the date of fetal infection. The association of specific IgA and IgM antibodies was more common in maternal contamination during the third trimester. IgA antibodies were detected in some cases with an absence of specific IgM in maternal contamination during the second trimester of pregnancy. The detection 
Table 3 Prenatal diagnosis of congenital toxoplasmosis: results of specific IgA and IgM antibodies response and inoculation into mice of fetal blood

\begin{tabular}{llllll}
\hline Cases & $\begin{array}{l}\text { Date of maternal } \\
\text { infection } \\
\text { (amenorrhea weeks) }\end{array}$ & $\begin{array}{l}\text { Data of fetal } \\
\text { blood sampling } \\
\text { (amenorrhea weeks) }\end{array}$ & $\begin{array}{l}\text { Specific IgM } \\
\text { antibodies }\end{array}$ & $\begin{array}{l}\text { Specific IgA } \\
\text { antibodies }\end{array}$ & $\begin{array}{l}\text { Inoculation } \\
\text { into mice }\end{array}$ \\
\hline 1 & 18 & 27 & 0 & 0 & + \\
2 & 22 & 29 & 0 & 0 & + \\
3 & 28 & 33 & 0 & 0 & + \\
4 & 25 & 32 & + & 0 & + \\
5 & 25 & 32 & + & 0 & + \\
6 & 15 & 23 & 0 & + & 0 \\
7 & 23 & 32 & 0 & + & 0 \\
8 & 25 & 31 & + & + & + \\
9 & 20 & 26 & + & + & + \\
10 & 26 & 30 & + & +
\end{tabular}

0 negative result: + positive result

of specific IgM and IgA antibodies is associated with an increase in serum IgM (more than $15 \mathrm{mg} / \mathrm{ml}$ ) and IgA (more than $3 \mathrm{mg} / \mathrm{ml}$ ). This shows the fetal synthesis of immunoglobulins. IgA and $\operatorname{IgM}$ antibodies disappeared rapidly between one and two months after birth, but in some cases they persisted for a long time (24 months) (table 2). Among the 94 fetal samples corresponding to a prenatal diagnosis of congenital toxoplasmosis 16 fetuses were infected. We tested the production of IgA and $\operatorname{IgM}$ antibodies in 10 infected fetuses. Specific IgA antibodies were never detected in the control group and in uninfected fetuses. They were detected in four cases of fetal infection. They were associated with specific IgM in two cases (table 3 ). IgA and IgM antibodies were detected in fetal blood as early as week 24 of pregnancy. Mouse inoculation of fetal blood was positive in seven cases. In only one case was it associated with IgA antibodies (table 3 ).

\section{Discussion}

We studied the IgA and IgM antibody response during acquired and congenital toxoplasmosis. In acquired toxoplasmosis IgM and IgA antibodies rise in parallel. The peak concentration of $\operatorname{IgA}$ antibodies is reached later than that of IgM antibodies. IgA antibodies persist over the three or four months following infection. These results confirm those reported by us and several other authors in acquired toxoplasmosis. $^{7-11}$ IgA antibodies associated with IgM antibodies indicate acute infection because they are not usual in acquired immunity and very rare in chronic infection. On the other hand, the absence of $\operatorname{IgA}$ antibodies does not exclude a recent infection. Results depend on the date of blood sampling in relation to infection. In early acute infection and at the end of infection they cannot be detected. In $5 \%$ of cases they are never detected during infection. The kinetics of IgA and IgM antibodies have been studied in experimental toxoplasmosis. ${ }^{12-13}$ An early and simultaneous rise in serum IgA and IgM antibodies was observed during experimental infections of rats and mice. Moreover, naturally occurring IgM antibodies or rheumatoid factors are not positive in the IgA immunocapture assay.

Our results show the value of IgA immuno- capture assay in prenatal, neonatal, and postnatal diagnosis of congenital toxoplasmosis. In neonatal diagnosis they confirm those of Decoster et al, ${ }^{9}$ Le Fichoux et $a l^{7}$, Pinon et $a l^{8}$ and Stepick Biek et al. ${ }^{11}$ Like these authors, we conclude that IgA antibodies are useful for the diagnosis of congenital toxoplasmosis and have to be sought. IgA antibodies are more frequently detected than IgM antibodies $75 \%$ of the cases had IgA antibodies, $61 \%$ IgM antibodies). No study of antenatal diagnosis has been published. We detected specific IgA antibodies in fetal blood. This shows that immunoglobulins were manufactured by the fetus. In fetal blood IgA antibodies are not always associated with IgM antibodies. Mouse inoculation of fetal blood was positive in seven cases with a median time to positivity, using this technique, of one month. In only one case were IgA antibodies and isolation of $T$ gondii positive. In most cases parasitemia seemed to have finished when IgA antibodies were detected. IgM and IgA antibody responses were studied in prenatal diagnosis of congenital rubella. In this infection IgA antibodies were detected in fetal samples but were always associated with IgM antibodies. ${ }^{14}$ In toxoplasmosis IgA antibodies seem to be manufactured longer then specific IgM. The study of the humoral immune response against $T$ gondii shows an intense IgA antibody response associated with IgM and IgG antibodies. The demonstration of IgA antibodies using serological tests may be useful for the diagnosis of acquired and congenital toxoplasmosis.

We thank Tomasa Estève and Michel Mathieu for their technical assistance.

1 Potasman I, Araujo FG, Remington JS. Toxoplasma antigens recoonized by naturally occuring human antibodies. gens rin Microbiol 1986;24:1050-6.

2 Berrebi A, Reme JM, Bessières MH et al. Diagnostic anténatal de la Toxoplasmose: à propos de 77 observations. Medecine et Hygiène 1989;47:976-82.

3 Ambroise-Thomas P, Garin JP, Rigaud P. Amélioration de la technique d'immunofluorescence par l'emploi de contrecolorants. Application à la Toxoplasmose. Presse Méd 1966;74:2215-6

4 Recurt-Carrere MP, Bessières MH, Seguéla JP. Evaluation d'un test ELISA de détermination des IgM et IgG sériques dans la Toxoplasmose humaine. Medecine et Maladies Infectieuses 1987;10:561-7.

5 Desmonts G, Naot Y, Remington JS. Immunoglobulin $M$-Immunosorbent assay for diagnosis of infectious diseases: diagnosis of acute congenital and acquired Toxoplasma infections. $\mathcal{f}$ Clin Microbiol 1981;14: 486-91.

6 Bessières MH, Cazaux M, Estève T, Menou JM, Colin F, Séguéla JP. Toxoplasmose congénitale: dosage de pro- 
téines sériques permettant un diagnostic précoce de l'infection et la prévention des complications. Bulletin Société Française de Parasitologie 1984;3:93-6.

7 Le Fichoux $Y$, Marty $P$, Chan $H$ Les IgA sériques spécifiques dans le diagnostic de la Toxoplasmose. Annales de Pediatrie (Paris), 1987;34:375-9.

8 Pinon JM, Thoannes H, Pouletty PH, Poirriuz J, Damiens J, Pelletier P. Detection of IgA specific for Toxoplasmosis in serum and cerebrospinal fluid using a non-enzymatic IgASerum and cerebrospinal fluid using a non-enzym

9 Decoster A, Darcy F, Caron A, Capron A. IgA antibodies against P30 as markers of congenital and acute Toxoplasmosis. Lancet 1988;ii:1104-6.

10 Favre G, Bessières MH, Séguèla JP. Dosage des IgA sériques spécifiques de la Toxoplasmose par une méthode ELISA. Application à 120 cas. Bulletin de la Société Française de Parasitologie 1984;3:139-42. 11 Stepick-Biek P, Thulliez P, Araujo FG, Remington JS. IgA
antibodies for diagnosis of acute congenital and acquired Toxoplasmosis. F Infect Dis 1990;162:270-3.

12 Godard I, Darcy F, Deslee D, Dessaint JP, Capron A Isotypic profiles of antibody responses to Toxoplasma gondii infection in rats and mice: kinetic study and characterization of target antiens of immunoglobulin A characterization of target antiens of immu

13 Chardes T, Bourgiun I, Mevelec MN, Dubremetz JF, Bout D. Antibody responses to Toxoplasma gondii in sera, intestinal secretions, and milk from orally infected mice and characterization of target antigens. Infect Immun and characteriza

14 Grangeot-Keros L. Pillot J, Daffos F, Forestier F Prenatal and postnatal production of IgM and IgA antibodies to Rubella virus studied by antibody capture immunoassay. f Infect Dis 1988;158:138-43. 